\title{
RISK ASSESSMENT OF NEARSHORE HAZARD AND VULNERABILITY USING THE ENTROPY METHOD
}

\author{
LIEN-KWEI CHIEN, CHI-WEN HUANG, WEI-PO HUANG \& CHENG-YU KU \\ Department of Harbor and River Engineering, Center of Excellence for the Ocean, \\ National Taiwan Ocean University, Taiwan
}

\begin{abstract}
Taiwan is an island surrounded by sea: the area of land is small. Population increases have increased the demand for land development; however, development in the inland plain has reached saturation. In addition to the opening of coastal defense in recent years, the coastal zone, including shore land and nearshore areas, has become an indispensable space. Development has diversified the use of the coastal zone; however, there is high concern toward the marine areas in any future development of the national land space. This study adopted the operational definition of disaster risk presented by the United Nations Disaster Relief Organization (UNDRO) in 1979. Moreover, we used 200 x $200 \mathrm{~m}^{2}$ digital grids to evaluate the risk level caused by existing levels on the typhoon-prone nearshore areas of Taiwan. The utilization of marine areas is expected to enable our sustainable development. Therefore, the vulnerability indicators we selected were in reference to sustainable development; and included social, economic, and environmental factors; the resilience of the marine economic scale; the assessment of environmentally sensitive areas; marine geology; marine depth; and the offshore distances. The entropy method was adopted in order to establish the vulnerability index rank. This study used the risk matrix to combine the level of hazard with vulnerability. The geographic information system was used to display the risk map on the coastal area. We established a local risk assessment model for hazard and vulnerability in the coastal areas of Taiwan.
\end{abstract}

Keywords: nearshore areas, risk assessment, entropy method, typhoon, geographic information system, risk mapping.

\section{INTRODUCTION}

Taiwan is in the center of the Western Pacific typhoon area, and is often hit by typhoons during the summer and autumn seasons. Strong wind and wave loads induced by extreme weather cause mostly direct impact on the current land use and the structures in coastal areas such as in the shore lands and nearshore areas. For example, storm surges in low-lying areas can cause disaster during typhoons. Taiwan is surrounded by the sea, and its flat land area is small. The increase in population has resulted in a high population density on the plain and coastal area. This high population density is responsible for the saturation of land development in the inland plain area. In addition to the opening of coastal defense in recent years and its abundant resources in the marine area, the coastal zone has become an indispensable space. The use of marine areas for development will become critical in the near future. Several scholars have conducted disaster risk assessments for the land use in the shore area, but few have evaluated the risk level posed by existing legal use in the nearshore area. The aim of this study was to evaluate the overall use and environment in the nearshore area, to assess whether the current usage is suitable. The results of this study are expected to indicate the risk level of the nearshore areas in Taiwan: they may be applied to the designation of marine resource zones for the National Land Plan and could provide the central government agency with a reference for land planning and management. In addition, the results of this study can enable sustainable development in the coastal areas.

\section{RESEARCH METHODOLOGY}

This section details the methods used to analyze the vulnerability risk in the nearshore areas. 


\subsection{Risk matrix}

This study adopted the operational definition of disaster risk of the United Nations (UN) Disaster Relief Organization (UNDRO) [1], as shown in eqn (1), to conduct the risk assessment of hazard and vulnerability in the nearshore areas

$$
\text { Risk }=H(\text { hazard }) \times V(\text { vulnerability }) \text {. }
$$

A risk matrix was used to combine hazard with vulnerability, and the results can be classified as shown in Fig. 1. In a risk matrix, the seriousness of the damage to an affected area is related to the intensity and frequency of disaster. We represented the disaster risk of a region as follows:

\begin{tabular}{|c|c|c|c|c|c|}
\hline Hazard & $\begin{array}{c}\text { Level } \\
1\end{array}$ & $\begin{array}{c}\text { Level } \\
2\end{array}$ & $\begin{array}{c}\text { Level } \\
3\end{array}$ & $\begin{array}{c}\text { Level } \\
4\end{array}$ & $\begin{array}{c}\text { Level } \\
5\end{array}$ \\
\hline $\begin{array}{c}\text { Level } \\
1\end{array}$ & 1 & 2 & 3 & 4 & 5 \\
\hline $\begin{array}{c}\text { Level } \\
2\end{array}$ & 2 & 4 & 6 & 8 & 10 \\
\hline $\begin{array}{c}\text { Level } \\
3\end{array}$ & 3 & 6 & 9 & 12 & 15 \\
\hline $\begin{array}{c}\text { Level } \\
4\end{array}$ & 4 & 8 & 12 & 16 & 20 \\
\hline $\begin{array}{c}\text { Level } \\
5\end{array}$ & 5 & 10 & 15 & 20 & 25 \\
\hline $\begin{array}{c}\text { Risk } \\
\text { level }\end{array}$ & $\begin{array}{c}\text { Level } \\
1\end{array}$ & $\begin{array}{c}\text { Level } \\
2\end{array}$ & $\begin{array}{c}\text { Level } \\
3\end{array}$ & $\begin{array}{c}\text { Level } \\
4\end{array}$ & $\begin{array}{c}\text { Level } \\
5\end{array}$ \\
\hline
\end{tabular}

Figure 1: Risk matrix.

\subsection{Entropy method}

In the past, most vulnerability analyses in marine areas have adopted the analytic hierarchy process and the Delphi method. The two methods are usually combined to analyze vulnerability. In the combined method, systematic and repeated surveys are conducted through expert questionnaires, which yield an expert consensus. In addition, the combined method can present complex factors in a hierarchical structure and it demonstrates the priority and weight of each factor by a numerical value, but the combined method requires additional time and effort to investigate and analyze the results. Therefore, this study refers to Zhang et al. [2], who used the entropy method to conduct a risk assessment of the red tide disaster in 2015, where they deduced the weight of the vulnerability index through that entropy method. The entropy method relies on the variability of the indicator to determine the objective weight of each indicator. If the entropy index $(E i)$ is small, then the degree of variation of the representation index is high, and more information is provided [3], [4].

The process of determining the weight of each indicator through the entropy method is demonstrated as follows: 


\subsubsection{Data standardization}

The data of the indicator is standardized.

Positive indicators: The standardization formula for positive indicators is:

$$
x_{i j}^{\prime}=\frac{x_{i j}-\min _{x_{j}}}{\max _{x_{j}}-\min _{x_{j}}} .
$$

Negative indicators: The standardization formula for negative indicators is:

$$
x_{i j}^{\prime}=\frac{\max _{x_{j}}-x_{i j}}{\max _{x_{j}}-\min _{x_{j}}},
$$

where $X_{i j}$ is the value of the $j$-th indicator in the $i$-th grid; $\min _{i j}$ is the minimum value of the $j$-th indicator; $\max _{i j}$ is the maximum value of the $j$-th indicator.

2.2.2 The entropy of each indicator

After the indicators are standardized, the entropy of each indicator is obtained. The entropy is calculated as follows:

$$
\begin{gathered}
E_{j}=-\ln (n)^{-1} \sum_{i=1}^{n} p_{i j} \ln \left(p_{i j}\right), \\
p_{i j}=\frac{x_{i j}^{\prime}}{\sum_{i=1}^{n} x_{i j}^{\prime}},
\end{gathered}
$$

where $\mathrm{p}_{\mathrm{ij}}=0$, then $\mathrm{p}_{\mathrm{ij}} \ln \left(\mathrm{p}_{\mathrm{ij}}\right)=0$, and where $n$ is the number of research units.

2.2.3 The weight of each indicator

After obtaining the entropy of each indicator, the weight of each indicator is calculated according to the entropy. The weight of each indicator is calculated as follows:

$$
w_{i}=\frac{1-E_{j}}{k-E_{j}} \quad(j=1,2 \ldots k),
$$

where $k$ is the number of indicators.

\section{ANALYSIS RESOURCES OF DATABASE}

\subsection{General introduction of study area}

The purpose of this study is to conduct a comprehensive investigation into the environment and use of marine areas in the island of Taiwan, to enable sustainable development and the use of resources in nearshore areas. To distinguish the hazard in nearshore areas, this study selected to use the definition of nearshore area given in the Coastal Zone Management Act of Taiwan and it focused on Taiwan as the study area [5]. According to the act, the nearshore 
area is the area from the average high tide line to the $30 \mathrm{~m}$ isobath or 3 nautical miles in the seaward direction, whichever is farther; but not exceeding the territorial sea, its seabed, or subsoil. To highlight the difference in risk level caused by the nonuniformity in the nearshore area, we used $200 \times 200-\mathrm{m}^{2}$ digital grids to evaluate the risk level of hazard and vulnerability in the nearshore area of Taiwan. The study area is shown in Fig. 2.

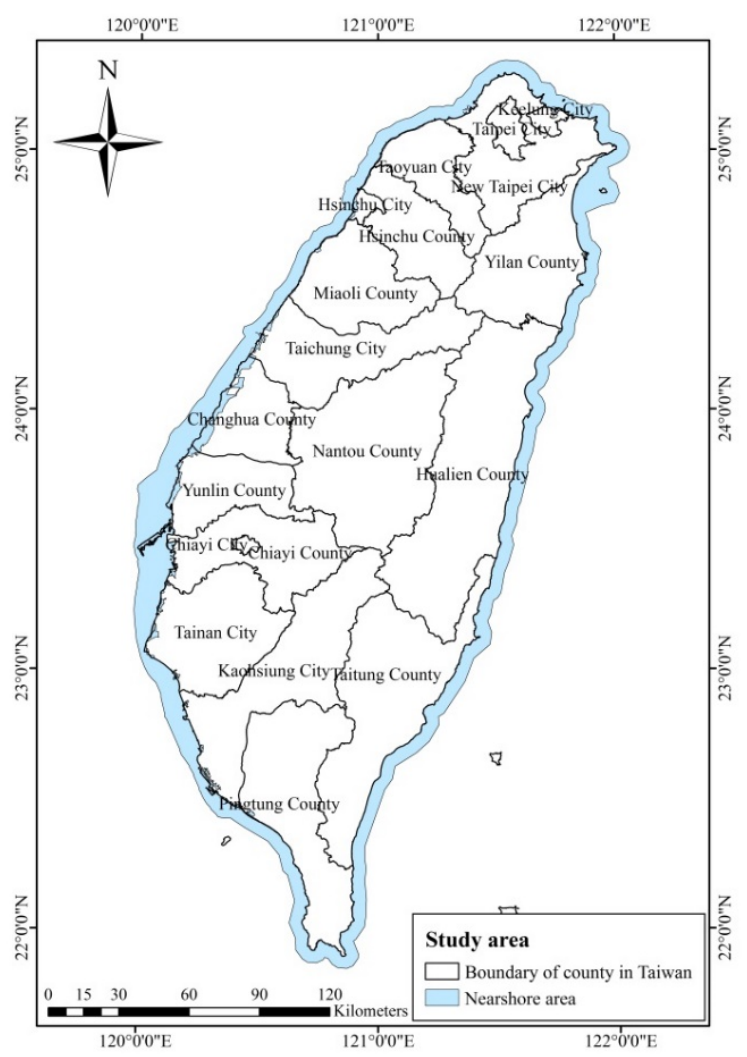

Figure 2: Study area: nearshore areas of Taiwan.

\subsection{Hazard indicators in the nearshore area}

Global climate change has increased the frequency and severity of disasters worldwide, and has intensified the losses incurred in coastal areas, as well as threatened the safety of both lives and property. When implementing coastal land development, the probability and intensity of extreme disasters must be considered, to avoid the destruction of facilities and buildings, and to assess the impact on lives and the economy.

In this study, typhoons were selected as the hazard indicator, because marine areas are prone to disasters caused by typhoons. This study considers that marine use is mainly affected by waves, and that waves are caused by wind. If the waves and the wind are taken into consideration at the same time, there will be overlapping factors. Therefore, only wave height is used for hazard analysis. In this study, wave height was obtained from the Water Resource Planning Institute, Water Resource Agency, Ministry of Economic Affairs of Taiwan (in 
2014) [6]. A numerical model was used to reproduce every typhoon event from 1980 to 2013, for recurrence period analysis and for obtaining wave heights.

This study used the waves caused by typhoons in 50-100 year return periods, to conduct the hazard analysis. Predicted wave heights in different marine areas are shown in Fig. 3.

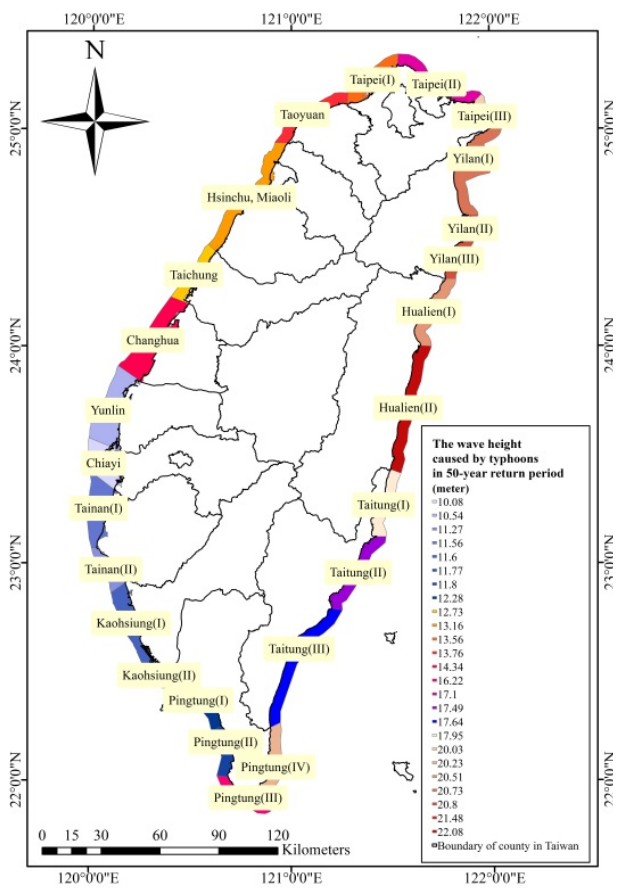

(a)

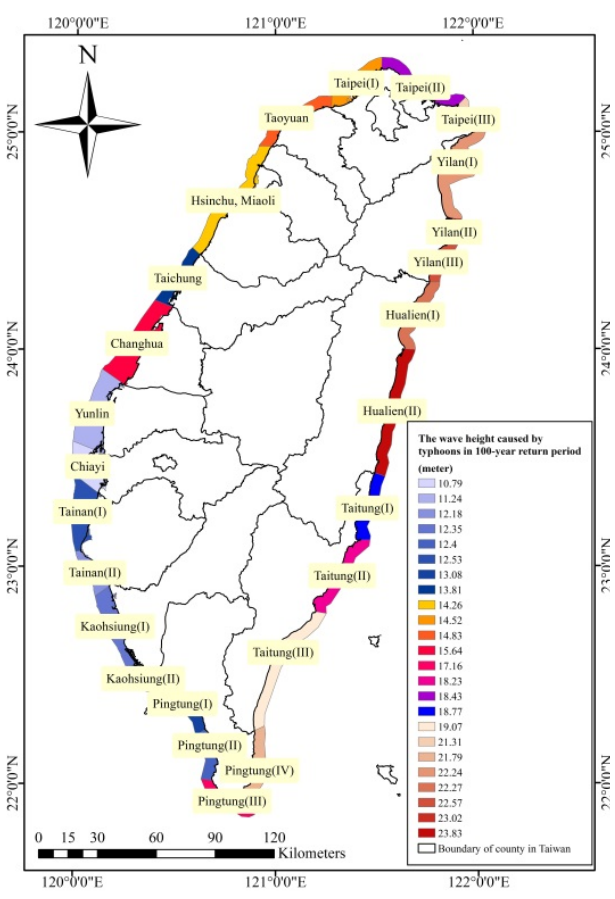

(b)

Figure 3: The wave heights caused by the typhoons in 50-year and 100-year return periods. (a) Wave heights caused by the typhoons in a 50-year return period; (b) Wave heights caused by the typhoons in a 100-year return period.

\subsection{Vulnerability indicators in nearshore areas}

The purpose of this study was to investigate the effect of wave vulnerability from previous typhoons on the development and use of nearshore areas. Our results can help enable sustainable development in nearshore areas in Taiwan. Therefore, vulnerability indicators were selected with reference to sustainable development which included social, economic and environmental factors; as well as a resilience measure to assess the vulnerability of land uses to typhoon wave action in nearshore areas. This study referred to studies on disaster risk assessment in marine areas. The risk assessment of marine areas was determined to be focused on a single disaster or single type of land use and the selected vulnerability indicators were partially applicable to the environment of the marine area in Taiwan. Therefore, this study also referred to the vulnerability indicators for disaster risk assessment in coastal areas.

The focus of this study was to assess the risk caused by land use in marine areas. Existing legal use of the marine area was adopted as a database to use to evaluate vulnerability, by using an economic scale. When conducting development in marine areas of Taiwan, the 
marine environment must first be considered; therefore, environmentally sensitive areas, marine geology and marine depth were selected as environmental indicators. In addition to the negative vulnerability indicators, risk must be assessed based on the resilience of the study area. In this study, we adopted the resilience indicator proposed in 2013 by Li et al. [7], and the offshore distance was selected as one of the vulnerability indicators. Therefore, the vulnerability indicators applicable to the marine environments of Taiwan included: environmentally sensitive areas, marine geology, marine depth, economic scale and offshore distance. The definitions of these vulnerability indicators are shown in Table 1.

Table 1: Vulnerability indicators.

\begin{tabular}{|c|c|c|}
\hline Indicators & Definition & Source \\
\hline $\begin{array}{l}\text { Existing legal } \\
\text { use of marine } \\
\text { area }\end{array}$ & $\begin{array}{l}\text { This study mainly explores the risk caused by the } \\
\text { current uses in the nearshore areas. The use is } \\
\text { based on the permit of land use, regulated by } \\
\text { Article 6(3) of "Regulations on Non-urban Land } \\
\text { Use Control" as revised and announced } 31 \\
\text { December } 2015 \text {. }\end{array}$ & $\begin{array}{l}\text { CECI Engineering } \\
\text { Consultants } \\
\text { Chih-Hsiang Hsu } \\
\text { (Representative } \\
\text { aspect: social) [8] }\end{array}$ \\
\hline $\begin{array}{l}\text { Economic scale } \\
\text { of marine area }\end{array}$ & $\begin{array}{l}\text { According to the existing legal use of the marine } \\
\text { area, the marine economic scale is } \\
\text { comprehensively evaluated by the presence or } \\
\text { absence of facilities, the overlapping use of the } \\
\text { marine area and the scale of use. }\end{array}$ & $\begin{array}{l}- \\
\text { (Representative } \\
\text { aspect: economic) }\end{array}$ \\
\hline $\begin{array}{l}\text { Environmentally } \\
\text { sensitive areas }\end{array}$ & $\begin{array}{l}\text { Environmentally sensitive areas are basically } \\
\text { equipped with special biologic value or are } \\
\text { highly vulnerable to environmental impact due to } \\
\text { improper development activities. If there are } \\
\text { primary and secondary environmentally sensitive } \\
\text { areas within the marine area, this marine area is } \\
\text { not suitable to develop. That is, the vulnerability } \\
\text { of the marine area is deemed larger. }\end{array}$ & $\begin{array}{l}\text { CECI Engineering } \\
\text { Consultants } \\
\text { (Representative } \\
\text { aspect: } \\
\text { environmental) [9] }\end{array}$ \\
\hline Marine geology & $\begin{array}{l}\text { When developing a land or marine area, the } \\
\text { geology must be considered if facilities are built } \\
\text { in the area. If the geology of the region is } \\
\text { weaker, that region is not suitable to develop. } \\
\text { Thus, the vulnerability of a marine area is larger. }\end{array}$ & $\begin{array}{l}\text { Central Geological } \\
\text { Survey } \\
\text { (Representative } \\
\text { aspect: } \\
\text { environmental) } \\
\end{array}$ \\
\hline Marine depth & $\begin{array}{l}\text { If the marine depth is deeper, the influence } \\
\text { caused by waves in that marine area is smaller. } \\
\text { Namely, the vulnerability of that marine area is } \\
\text { smaller. }\end{array}$ & $\begin{array}{l}\text { The Naval } \\
\text { Meteorological and } \\
\text { Oceanographic } \\
\text { Office } \\
\text { (Representative } \\
\text { aspect: } \\
\text { Environmental) } \\
\end{array}$ \\
\hline $\begin{array}{l}\text { Offshore } \\
\text { distance }\end{array}$ & $\begin{array}{l}\text { The offshore distance reflects the efficiency of } \\
\text { emergency rescue. If the offshore distance of a } \\
\text { marine area is farther, the efficiency of } \\
\text { emergency rescue is lower. It means that } \\
\text { resilience is smaller, but vulnerability is larger in } \\
\text { that marine area. }\end{array}$ & $\begin{array}{l}\text { (Representative } \\
\text { aspect: resilience) }\end{array}$ \\
\hline
\end{tabular}




\section{ANALYSIS RESULTS}

\subsection{Hazard analysis in nearshore areas}

Typhoons were used as the hazard indicators in nearshore areas, because Taiwan is often hit by typhoons in the summer and autumn seasons. The historical typhoon wave simulation of the Water Resource Planning Institute, Water Resource Agency, Ministry of Economic Affairs of Taiwan was adopted as analytical data for our study.

The wave heights caused by typhoons in 50-year and 100-year return periods were converted into wave energy by using eqn (7), to yield the disaster potential of any given typhoon wave:

$$
\text { Wave energy }=(1 / 8) \rho g h^{2},
$$

where $\rho$ is the density of sea water $\left(1.01 \mathrm{~N} / \mathrm{m}^{3}\right), g$ is the acceleration due to gravity (9.81 $\left.\mathrm{m} / \mathrm{s}^{2}\right), h$ is the wave height $(\mathrm{m})$, and the wave energy has units $\mathrm{N} / \mathrm{m}^{2}$.

Our study used statistics to rank the wave energy caused by past typhoons hitting Taiwan during the 50- and 100-year return periods. Their wave energy was normalized with absolute zero. That is, when there was no wave in the marine area, its normalization value was 0 . The normalization value of the maximum wave energy calculated in this study was 100 . The wave energy of other marine areas was interpolated to obtain normalized values, and the normalized values were graded at intervals of $20 \%$. Thus, our typhoon wave hazard values are divided into five levels, as shown in Fig. 4.

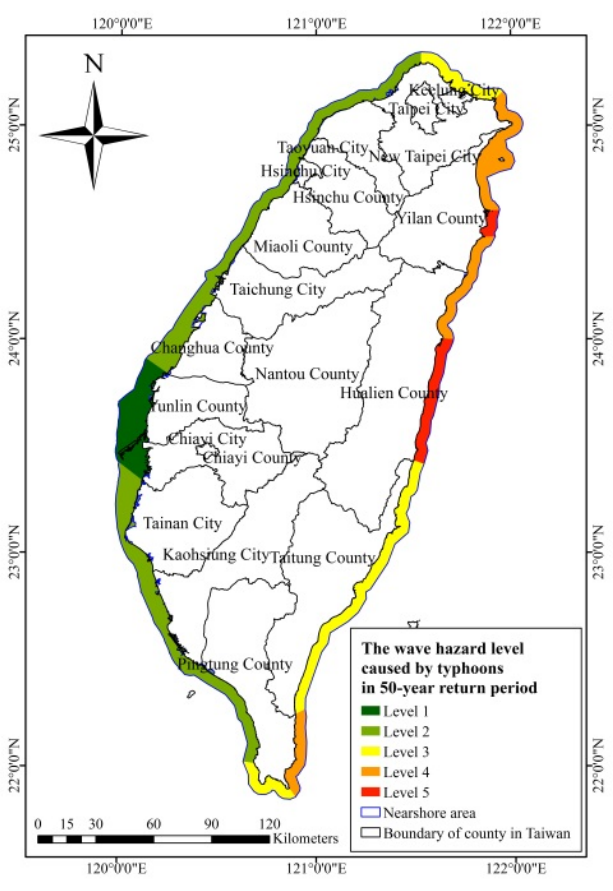

(a)

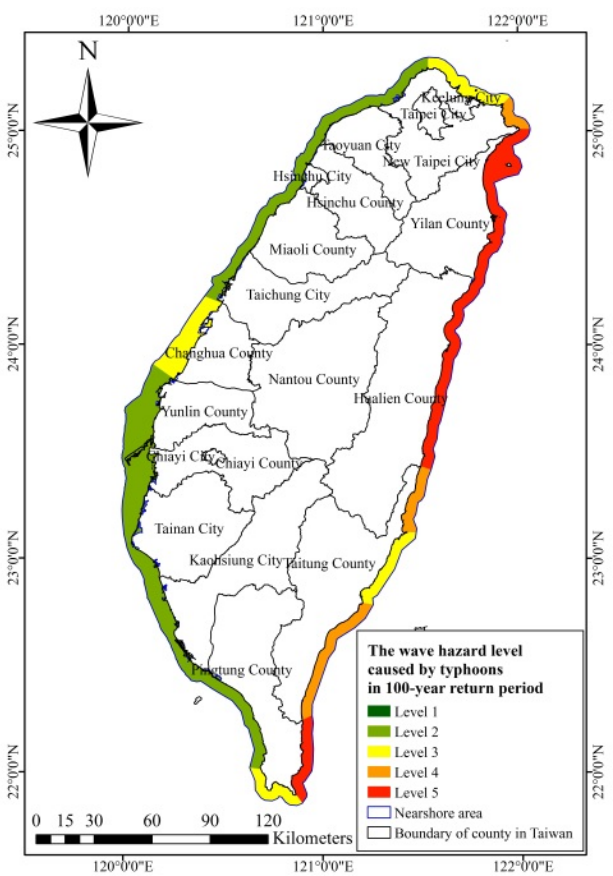

(b)

Figure 4: Maps of typhoon wave hazard levels. (a) The 50-year return period; and (b)The 100-year return period. 


\subsection{Vulnerability analysis in the nearshore area}

In this study, vulnerability was defined as the level of loss that society, nature, and the region may experience. The waves caused by typhoons result in severe losses in the nearshore areas.

A vulnerability analysis was conducted using social, economic, environmental and resilience indicators. The vulnerability level was ranked using the entropy method. The entropy method is an objective method used to allot weight to each indicator. It is used to evaluate the risks of development and utilization for marine areas.

4.2.1 Description of the indicators in the nearshore area

The vulnerability indicators of this study are as follows:

- $\quad$ Representative indicator - Social: Existing legal use of marine areas

The focus of this study was the risk assessment of current land use in nearshore areas. Therefore, this study adopted and digitalized, in 2016, the location permit documents of competent authorities collected by the Construction and Planning Agency of the Ministry of the Interior of Taiwan [8].

- $\quad$ Representative indicator - Economic: Economic scale of marine areas Based on the existing legal land use in marine areas, operational feasibility was evaluated through the overlapping use, the presence or absence of facilities, and the scale (area) of use, rather than through the output of each existing legal use. If the overlapping and the scale of use in study units were large, then the scale of economic activity is seen as high. Experimental analysis proved that vulnerability was directly proportional to the destruction caused by disasters. If there is a facility in the study unit, then the additional cost of repairs must be paid in the event of a disaster. Thus, we could see if the vulnerability in the study unit was greater. In this study, the scale of the marine economy was combined with the presence or absence of facilities, overlapping use and the scale of use in equal measure. The calculation formula for this is shown in eqn (8):

Economic scale of marine area

$$
=(\text { presence of facilities }+ \text { overlapping of use }+ \text { the scale of use }) / 3 \text {. }
$$

- $\quad$ Representative indicator - Environmental: Environmentally sensitive areas

Environmentally sensitive areas have special biological value and are highly vulnerable to environmental impact, due to improper development activities. If there are primary and secondary environmentally sensitive areas within the grid, then the vulnerability is the highest. If there is no environmentally sensitive area within the grid, then the vulnerability is the lowest. Because the environmentally sensitive areas are not quantitative in nature, this indicator must be quantified before conducting the vulnerability analysis: our study assigned a relative score for each situation. When there were primary and secondary environmentally sensitive areas within the grid, we assigned a score of 3 . When there were primary environmentally sensitive areas in the grid, this score was 2 . If there were secondary environmentally sensitive areas in the grid, the score was 1 . If there was no environmentally sensitive area in the grid, then the score was 0 .

- $\quad$ Representative indicator - Environmental: Marine geology

Geology is one of the most important factors to be considered when building in the marine area. Areas with weak geology have high vulnerability. To evaluate this indicator, this study scaled the distribution of sediments in the marine areas of Taiwan by $1: 500,000$. If the geology indicated a large number of corals, it represented the 
highest vulnerability. If the geology was composed mostly of medium gravel or rock, it indicated there was the lowest vulnerability. As marine geology is not quantitative, hence, the relative scores based on the vulnerability of marine sediments were assigned before conducting the vulnerability analysis in the nearshore area. The relative scores of marine sediments are shown in Table 2.

Table 2: Relative scores of marine sediments.

\begin{tabular}{|l|c|c|}
\hline Sediments & Vulnerability & Relative score \\
\hline Medium gravel-rock & 6 & 1 \\
\hline Fine gravel & 5 & 2 \\
\hline Sandy & 4 & 3 \\
\hline Sandy with Silt & 3 & 4 \\
\hline Silt & 2 & 5 \\
\hline Coral & 1 & 6 \\
\hline
\end{tabular}

- $\quad$ Representative indicator - Environmental: Marine depth

The marine depth of nearshore areas was interpolated to points of depth, by using the Kriging method in the marine areas that had been investigated by the Naval Meteorological and Oceanographic Office. For this study, if the marine depth of the grid was higher, then it represented a smaller impact on wave action, and consequently, lower vulnerability. Conversely, if the marine depth of the grid was shallow, then it represented an area of high impact and thus, high vulnerability.

- $\quad$ Representative indicator - Resilience: Offshore distance

In this study, the offshore distance was selected as the vulnerability indicator representing resilience. A grid location farther from the shore would result in greater rescue difficulty; thus, the vulnerability would be seen as higher. Conversely, a grid location closer to the shore would result in a lower difficulty of receiving disaster relief and thus, lower vulnerability.

\subsubsection{Vulnerability analysis results in the nearshore area}

Based on the original data for each vulnerability indicator, we established our grid data. We used the entropy method to normalize the data for each vulnerability indicator, and then calculated their information entropy and weight. The information entropy and weight of vulnerability indicators in this study are shown in Table 3 . This study assessed the differences in vulnerability indicators and thus the vulnerability of the grids was calculated using eqn (9).

Vulnerability of the grids

$=\sum$ (Normalized value of vulnerability indicators*Weight).

Table 3: Information entropy and weight of vulnerability indicators.

\begin{tabular}{|l|c|c|}
\hline Vulnerability indicator & Ei (entropy) & Wi (weight) \\
\hline Marine geology & 0.98 & 0.131 \\
\hline Economic scale of marine & 0.97 & 0.292 \\
\hline Marine depth & 1.00 & 0.004 \\
\hline Environmentally sensitive area & 0.95 & 0.408 \\
\hline Offshore distance & 0.98 & 0.164 \\
\hline
\end{tabular}


The vulnerability of the grids was graded using the natural breaks (Jenks) method to obtain the different vulnerability levels in the nearshore area. The grading standard of the vulnerability level in the nearshore area was analyzed using the entropy method, calculated using the preceding method. The natural breaks (Jenks) method was used to speed up division into five vulnerability levels. This classification is shown in Table 4 . The vulnerability distribution and grading chart in the nearshore area is shown in Fig. 5.

Table 4: Grading standard of the vulnerability level in the nearshore area, as analyzed by the entropy method.

\begin{tabular}{|c|c|c|c|c|c|c|}
\hline & $\begin{array}{l}\text { Grading } \\
\text { method }\end{array}$ & Level 1 & Level 2 & Level 3 & Level 4 & Level 5 \\
\hline $\begin{array}{l}\sum \text { (Normalized value of } \\
\text { vulnerability indicators*Weight) }\end{array}$ & $\begin{array}{c}\text { Natural } \\
\text { breaks } \\
\text { (Jenks) }\end{array}$ & $\begin{array}{c}0.00 \\
1 \\
0.18 \\
\end{array}$ & $\begin{array}{c}0.19 \\
\mid \\
0.27 \\
\end{array}$ & $\begin{array}{c}0.28 \\
1 \\
0.37 \\
\end{array}$ & $\begin{array}{c}0.38 \\
1 \\
0.48 \\
\end{array}$ & $\begin{array}{c}0.49 \\
\mid \\
0.77 \\
\end{array}$ \\
\hline
\end{tabular}

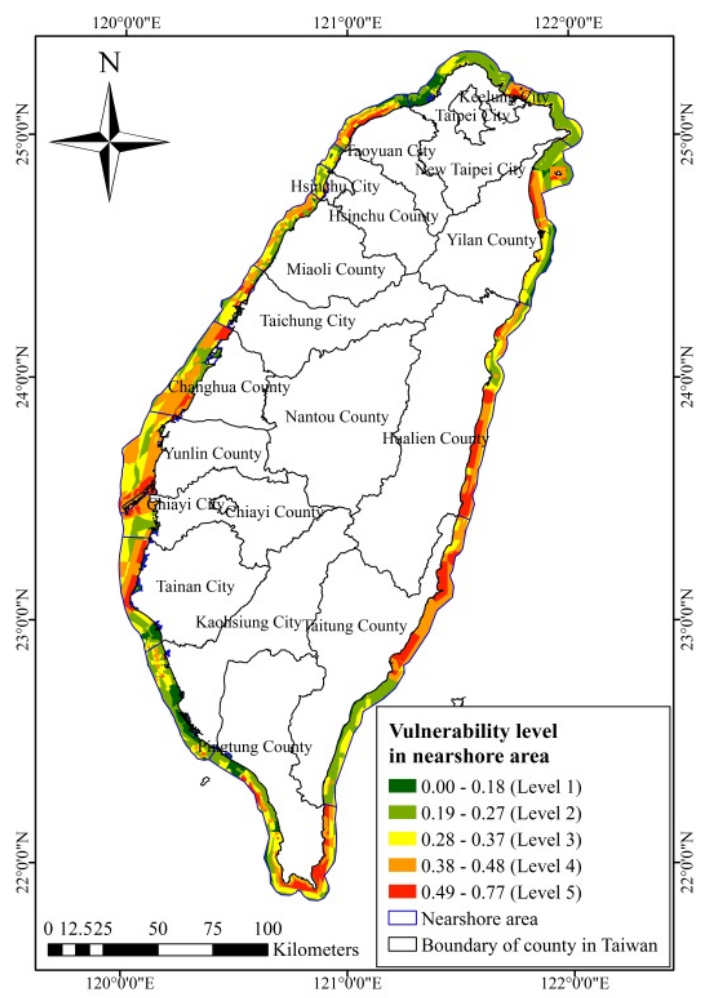

Figure 5: Distribution of vulnerability levels in the nearshore areas.

The results demonstrated that the weights of environmentally sensitive areas and the economic scale of the marine area were highest. Therefore, the high vulnerability levels, namely Level 4 and Level 5, were mainly distributed in areas with primary and secondary environmentally sensitive areas, as well as areas with a high economic scale. 
4.3 Risk assessment of hazard and vulnerability in the nearshore areas

In this study, the disaster risk is defined as the destruction of facilities, economic loss and the environmental damage in the nearshore area caused by the typhoon waves that had been historically present. Hazard is defined as the waves caused by the historically present typhoons. Vulnerability is defined as the connotation of sustainable development (including society, economy and environmental factors), and by adding the resilience to the present actual situation and environment of the nearshore area.

The waves caused by the typhoons were our hazard indicators. Vulnerability indicators included: marine economy, environmentally sensitive areas, marine depth, marine geology and offshore distance. Hazard and vulnerability were then combined, using a risk matrix, to obtain the disaster risk. The grading standard of risk according to the risk matrix is shown as Table 5. The risk distribution and grading chart in the nearshore area within the different return periods is shown in Fig. 6.

Table 5: Risk grading standards.

\begin{tabular}{|c|c|c|c|c|c|c|}
\hline & $\begin{array}{c}\text { Grading } \\
\text { method }\end{array}$ & Level 1 & Level 2 & Level 3 & Level 4 & Level 5 \\
\hline \multirow{2}{*}{ Risk } & Risk matrix & 0 & 6 & 11 & 16 & 21 \\
& & 5 & $\mid$ & $\mid$ & $\mid$ & $\mid$ \\
\hline
\end{tabular}

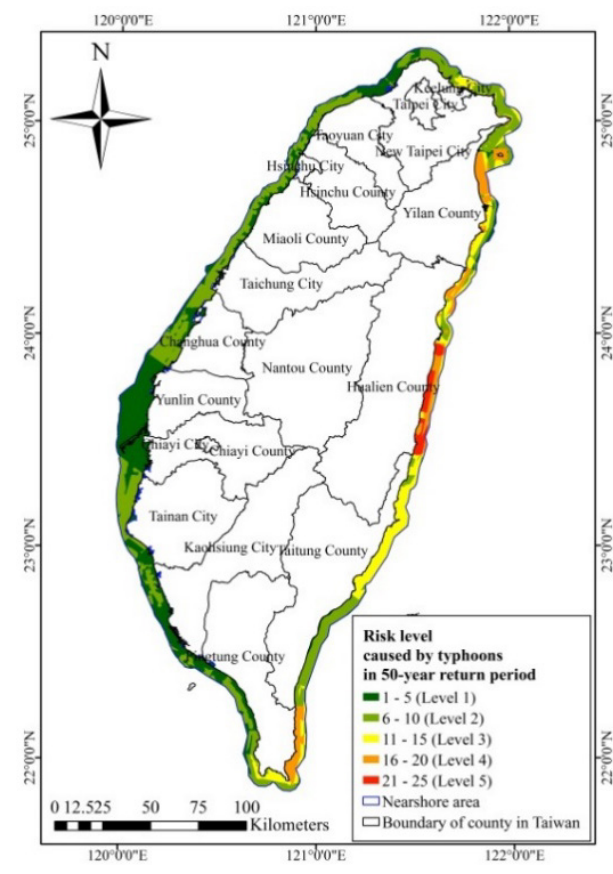

(a)

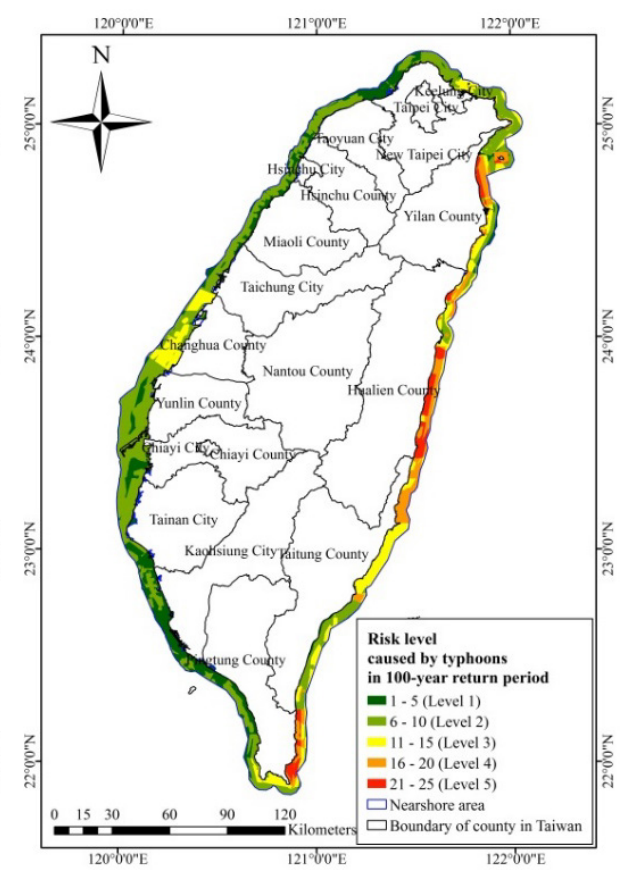

(b)

Figure 6: Risk levels in the nearshore areas. (a) Risk level caused by the typhoons that occurred in a 50-year return period; (b) Risk level caused by the typhoons that occurred in a 100-year return period. 


\section{CONCLUSIONS}

This study adopted the definition of disaster risk provided by UNDRO, and evaluated marine disasters caused by typhoons. Typhoons were selected as the hazard indicator: the wave heights caused by historical typhoons in the nearshore area were used to assess the typhoon disaster potential. The vulnerability indicators were selected on the basis of social, economic, and environmental factors; resilience of marine economic scale; environmentally sensitive areas; marine geology; marine depth; and offshore distance.

To highlight the difference in risk levels caused by the nonuniformity of land use in the nearshore areas and to assess the current highest precision grid topographic map of marine areas, we used $200 \times 200-\mathrm{m}^{2}$ digital grids as study units, to comprehensively reflect the risks of hazard and vulnerability in the marine area, and subsequently, connect with grids of topographic maps of the marine areas surrounding Taiwan. This study used the entropy method of object weighting to analyze vulnerability in nearshore areas. The weights of environmentally sensitive areas and the economic scale of a given marine area were the highest. Therefore, in this study, vulnerability was mainly influenced by environmentally sensitive areas and the economic scale of marine areas. Finally, this study used a risk matrix to combine the hazards and vulnerabilities, to obtain five grade levels for the risk of hazard and vulnerability in marine areas. The risk assessment in nearshore areas of Taiwan revealed that some of the nearshore areas have higher risk levels, due to typhoon waves, because of their disaster potential caused by typhoon waves during the previous 100-year return period. The risk levels in the nearshore areas of Ilan and Hualien were higher, due to the higher impact of typhoon waves. The multi-use nature meant that its economic scale is large compared with having a single use, and a harsh environment was seen in the nearshore areas of Ilan and Hualien.

This study used relevant indicators that are applicable to nearshore areas of Taiwan and combined the processes of hazard, vulnerability, and risk assessment to establish a localized risk assessment model for hazard and vulnerability in nearshore areas. The model could assist relevant agencies with a risk assessment for the planning and development of national Taiwanese land.

\section{ACKNOWLEDGEMENTS}

Special thanks for the financial support from project "Operation Permission Assessment of Coastal Area Land Development and Environmental Risk Management (1/2) (MOST 1062621-M-019-005-MY2)" of the Ministry of Science and Technology and the Center of Excellence for the Ocean of the National Taiwan Ocean University.

\section{REFERENCES}

[1] United Nations Disaster Relief Organization (UNDRO), Natural disaster and vulnerability analysis: Report of expert group meeting. UNDRO books: Geneva, 1979.

[2] Zhang, X.X., Xu, Z.Z., Cheng, J.Y. \& Shao, M.H., Assessment methods of red tide disaster risk: A case in Liaoning Coast. Fishery Science, 2015.

[3] Chen, W.L. \& Chen, T.H., Application of entropy and TOPSIS Method on evaluating decision-making model for Pin-Work design. Journal of Design Science, 11(1), pp. 2341, 2008.

[4] Kuo, S.L. \& Lee, S.H., Study of fuzzy comprehensive evaluation based on entropy. Management Sciences Research, pp. 43-48, 2013.

[5] Ministry of the Interior: Taiwan, Coastal Zone Management Act. 2015.

[6] The Assessment on Coastal Protection of Sea Dikes; Water Resources Planning Institute, Water Resources Agency, Ministry of Economic Affairs, Taiwan, 2014. 
[7] Li, Q., Zhang, R., Yao, X.F., Ge, S.S. \& Zou, H.W., Risk assessment and regionalization of tropical cyclone disaster over China's surrounding sea. Journal of Tropical Meteorology, 29(1), pp. 143-148, 2013.

[8] Discussion on the location permit mechanism of marine area of non-urban land; Construction and Planning Agency Ministry of the Interior, Taiwan, 2016.

[9] Revised National Regional Plan; Ministry of the Interior, Taiwan, 2016. 